DOI: https://doi.org/10.47405/mjssh.v6i9.1043

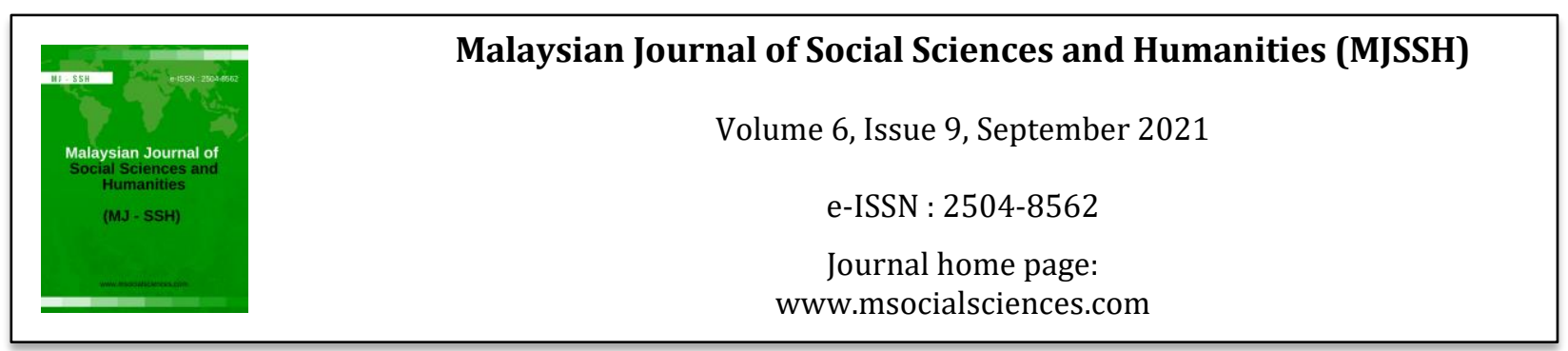

\title{
Isu dan Cabaran dalam Pelaksanaan Pendidikan Peringkat Rendah dan Menengah: Pendekatan Malaysia Semasa Pandemik Covid-19
}

\author{
Ainul Afzan binti Ramli' ${ }^{1}$ Ishak Bin Haji Abd Rahman ${ }^{1}$ \\ 1Fakulti Ekonomi dan Pengurusan, Universiti Kebangsaan Malaysia (UKM) \\ Correspondence: Ishak Bin Haji Abd Rahman (haq@ukm.edu.my)
}

\begin{abstract}
Abstrak
Asas pendidikan khususnya di peringkat rendah dan menengah adalah sangat penting dalam mencorak dan membentuk generasi baharu yang seimbang dari aspek intelektual, emosi, jasmani, rohani dan sahsiah, di samping mempunyai daya pemikiran yang kreatif, kritis dan berdaya saing dalam mempersiapkan diri untuk mendepani transformasi pendidikan di peringkat pengajian tinggi dan melahirkan modal insan yang berpengetahuan dan berkemahiran tinggi serta produktif dalam menghadapi pelbagai cabaran yang mendatang di abad ke-21 selaras dengan hasrat Dasar Pendidikan Negara Walau bagaimanapun, sistem pendidikan yang dilaksanakan di negara ini mengalami perubahan drastik dan terjejas teruk apabila semua sekolah perlu ditutup sepenuhnya berikutan negara berhadapan dengan krisis penularan pandemik Covid-19 yang kini menjadi fenomena yang amat membimbangkan rakyat di seluruh dunia. Situasi ini benar-benar memberi kesan yang mendalam kepada semua pihak berkepentingan terutamanya guru-guru dan murid-murid apabila kaedah pengajaran dan pembelajaran yang dahulunya dijalankan secara bersemuka perlu diubah kepada kaedah pembelajaran dari rumah (home-based learning), di samping keperluan mematuhi Standard Operation Standard (SOP) dan mempraktikkan norma-norma baharu dalam menjalani kehidupan seharian. Kajian ini akan membuat penelitian berhubung strategi yang telah diguna pakai oleh Kementerian Pendidikan Malaysia (KPM) sebagai peneraju sistem pendidikan negara dalam melaksanakan pelbagai inisiatif melalui pendekatan dan kaedah yang terbaik dalam mengatasi isu-isu dan cabaran yang timbul dalam sektor pendidikan, antaranya melaksanakan pendekatan pembelajaran dari rumah, pembatalan dan pindaan tarikh peperiksaan awam, merancang strategi pembukaan semula sekolah selepas tempoh PKP dan pindaan takwim persekolahan tahun 2020 demi memastikan proses pengajaran dan pembelajaran dapat diteruskan dan dalam masa yang sama membantu negara memerangi pandemik Covid-19 dalam tempoh Perintah Kawalan Pergerakan yang sedang dilaksanakan sehingga hari ini.
\end{abstract}

Kata kunci: pelaksanaan pendidikan, e-pembelajaran, pembelajaran dalam talian, Covid-19

\section{Issues and Challenges in the Implementation of Primary and Secondary Education: Malaysia's Approach During the Covid-19 Pandemic}

\begin{abstract}
The foundation of education, especially at the primary and secondary levels, is very important in shaping and shaping a new generation that is balanced intellectually, emotionally, physically, spiritually and personally, as well as having creative, critical and competitive thinking in preparing for educational transformation at the tertiary level and produce knowledgeable and highly skilled and
\end{abstract}


DOI: https://doi.org/10.47405/mjssh.v6i9.1043

productive human capital in facing the various challenges ahead in the 21st century in line with the aspirations of the National Education Policy . However, the education system implemented in the country underwent drastic changes and severely affected when all schools need to be closed completely following the country facing the Covid-19 pandemic contagion crisis which is now a phenomenon of great concern to people around the world. This situation really has a profound impact on all stakeholders, especially teachers and students when the teaching and learning methods that were previously conducted face to face need to be changed to home-based learning methods, in addition to the need to comply with the Standards. Operation Standard (SOP) and practice new norms in daily life. This study will examine the strategies adopted by the Ministry of Education Malaysia (MOE) as a leader in the national education system in implementing various initiatives through the best approaches and methods in overcoming issues and challenges that arise in the education sector, including implementing a home learning approach, cancellation and amendment of public examination dates, planning strategies for reopening schools after the PKP period and amendments to the 2020 school calendar to ensure the teaching and learning process can be continued and at the same time help the country fight the Covid-19 pandemic during the period of the Movement Control Order which is being implemented to this day.

Keywords: education implementation, e-learning, online learning, Covid-19

\section{Pengenalan}

Dasar Pendidikan di Malaysia pada hari ini adalah berteraskan kepada Falsafah Pendidikan Kebangsaan (FPK) yang termaktub di dalam Dasar Pendidikan Kebangsaan (DPK) yang telah dikemas kini dan ditambah baik pada tahun 2012. DPK yang pertama dihasilkan berpandukan Penyata Razak (1956) yang dimaktubkan dalam Ordinan Pelajaran (1957) dan Laporan Rahman Talib (1960) yang dimaktubkan dalam Akta Pelajaran (1961). Dasar ini kemudiannya telah dikaji semula oleh Jawatankuasa Kabinet pada tahun 1979 dan seterusnya Akta Pendidikan 1996 [Akta 550] digubal bertujuan supaya sistem pendidikan membolehkan masyarakat menguasai ilmu pengetahuan, kemahiran dan nilai murni yang diperlukan dalam dunia yang berdaya saing tinggi serta bersifat global kesan daripada perkembangan pesat sains, teknologi dan maklumat. Di dalam FPK, pendidikan di Malaysia digariskan sebagai satu usaha berterusan ke arah memperkembangkan potensi individu secara menyeluruh dan bersepadu untuk mewujudkan insan yang seimbang dan harmonis dari segi intelek, rohani, emosi dan jasmani berdasarkan kepercayaan dan kepatuhan kepada Tuhan. Usaha ini adalah bagi melahirkan rakyat Malaysia yang berilmu, bertanggungjawab dan berkeupayaan dalam mencapai kesejahteraan diri serta memberi sumbangan terhadap keharmonian dan kemakmuran masyarakat dan negara (Kementerian Pendidikan Malaysia, 2017).

Dalam merealisasikan DPN dan FPK, KPM sebagai peneraju dasar pendidikan negara bertanggungjawab untuk memastikan visi pendidikan negara iaitu "Pendidikan Berkualiti, Insan Terdidik, Negara Sejahtera" dan misinya iaitu "Melestarikan Sistem Pendidikan yang Berkualiti untuk Membangunkan Potensi Individu bagi Memenuhi Aspirasi Negara" dapat dicapai sebagaimana dihasratkan. Selain itu, KPM dengan usaha dan kerjasama seluruh warganya juga bertanggungjawab untuk menentukan empat (4) matlamat pendidikan negara dapat dicapai iaitu untuk melahirkan bangsa Malaysia yang taat setia dan bersatu padu; melahirkan insan beriman, berakhlak mulia, berilmu, berketerampilan dan sejahtera; menyediakan sumber tenaga manusia untuk keperluan kemajuan negara; dan memberi peluang pendidikan kepada semua warganegara Malaysia (Kementerian Pendidikan Malaysia, 2017).

Pelaksanaan DPK khususnya di peringkat pendidikan rendah dan menengah adalah bersandarkan kepada Sistem Pendidikan Kebangsaan (SPK) yang memperuntukkan tiga (3) teras utama iaitu penggunaan bahasa kebangsaan sebagai bahasa pengantar utama, menggunakan kurikulum yang sama dan menduduki peperiksaan yang sama. SPK juga memperuntukkan pendidikan yang diberikan adalah pelbagai dan komprehensif skopnya bagi memenuhi keperluan negara serta memupuk perpaduan melalui pembangunan budaya, sosial, ekonomi dan politik seiring dengan prinsip-prinsip Rukun 
DOI: https://doi.org/10.47405/mjssh.v6i9.1043

Negara. Secara konklusinya, pelaksanaan pendidikan berteraskan DPK amatlah penting bagi menjayakan wawasan negara demi mencapai taraf negara maju daripada aspek ekonomi, keadilan sosial, kekuatan rohani, moral dan etika ke arah mewujudkan suatu masyarakat yang bersatu padu, demokratik, liberal dan dinamik (Kementerian Pendidikan Malaysia, 2017).

\section{Pelan Pembangunan Pendidikan Malaysia 2013-2025}

Pelan Pembangunan Pendidikan Malaysia (PPPM) 2013-2025 adalah panduan dan tunjang utama dalam pengurusan sistem pendidikan di seluruh pelosok negara. PPPM merupakan pelan pembaharuan dasar pendidikan yang telah dikaji secara menyeluruh dan dilaksanakan melalui proses transformasi sistem pendidikan sedia ada yang bermatlamat untuk melengkapkan murid-murid di negara ini dengan segala kemahiran baharu yang mereka perlukan setanding dengan standard pendidikan antarabangsa sebagai persiapan diri mereka untuk merebut pelbagai peluang dan menghadapi cabaran di abad ke- 21 . Pelan ini menggariskan visi sistem pendidikan dan aspirasi murid secara individu yang perlu dicapai untuk memenuhi keperluan negara pada masa hadapan. Sebelas (11) anjakan utama yang terdiri daripada strategi dan operasi ditetapkan untuk dilaksanakan secara holistik oleh KPM bagi mentransformasikan sistem pendidikan negara serta mencapai visi dan aspirasi yang dihasratkan dalam tempoh 13 tahun tersebut iaitu melalui pencapaian keberhasilan dalam aspek akses, kualiti, ekuiti, perpaduan dan kecekapan. Selain menumpukan kepada keberhasilan dalam sistem pendidikan, setiap murid juga perlu dilengkapkan dengan tahap kualiti yang seimbang dari aspek pengetahuan, kemahiran berfikir, kemahiran memimpin, kemahiran dwibahasa, etika dan kerohanian serta identiti nasional (Kementerian Pendidikan Malaysia, 2013).

\section{Senario Pandemik Covid-19 di Malaysia}

Penduduk di seluruh dunia kini sedang berada dalam kebimbangan dan berwaspada menghadapi krisis penularan wabak koronavirus terbaharu yang mula dikesan di China pada 31 Disember 2019. Pertubuhan Kesihatan Sedunia (World Health Organization -WHO) pada 11 Februari 2020 telah mengumumkan nama wabak koronavirus terbaharu ini sebagai Koronavirus 2019 (Covid-19) dan mengisytiharkannya sebagai suatu pandemik kerana sifatnya yang mudah merebak dan penularannya begitu drastik di seluruh dunia pada 11 Mac 2020 (World Health Organization, 2020). Mengikut Kementerian Kesihatan Malaysia (KPM), Covid-19 adalah sejenis virus yang boleh menyebabkan jangkitan saluran pernafasan secara akut dan ianya berbeza daripada Severe Acute Respiratory Syndrome Coronavirus (SARS) dan Middle East Respiratory Syndrome-Related Coronavirus (MERS$\mathrm{CoV})$ yang pernah ditemui sebelum ini. Covid-19 ini boleh menyebabkan spektrum gejala kepada seseorang individu yang dijangkiti daripada mengalami selesema biasa kepada radang paru-paru (pneumonia) yang teruk (Kementerian Kesihatan Malaysia, 2020). Virus ini merebak melalui titisan cecair yang keluar ke udara dari hidung atau mulut individu yang dijangkiti kepada individu lain yang berada berdekatan apabila mereka batuk atau bersin. Ia juga boleh merebak pada objek-objek yang kerap disentuh seperti tombol pintu, tangga, butang lif, tangga, telefon dan sebagainya. Individu lain boleh dijangkiti apabila tangan mereka menyentuh objek atau permukaan yang tercemar dengan Covid-19 tersebut dan kemudiannya menyentuh bahagian muka yang berongga seperti mata, hidung atau mulut (Universiti Utara Malaysia, 2020).

Kebanyakan individu yang dijangkiti Covid-19 akan mengalami simptom-simptom seperti batuk, demam, sakit kepala, selesema, sakit tekak, muntah atau loya, menggigil, kelesuan, kejang otot atau cirit-birit. Dalam keadaan yang lebih teruk, individu tersebut juga boleh mengalami simptom seperti sesak nafas, sukar bernafas, sakit dada, hilang deria bau atau hilang deria rasa, yang kemudiannya boleh membawa kepada masalah radang paru-paru atau sindrom kecemasan respiratori akut terutamanya melibatkan individu yang mempunyai sejarah penyakit kronik seperti darah tinggi, kencing manis, masalah saluran pernafasan, kanser dan masalah jantung. Jangkitan virus ini sukar dikesan pada peringkat awal kerana ia mempunyai tempoh inkubasi dalam tubuh badan iaitu sekurangkurangnya dalam tempoh 5 hingga 6 hari atau sehingga 14 hari sebelum seseorang individu yang dijangkiti menunjukkan sebarang simptom jangkitan. Cara jangkitan dan simptom-simptom yang 
dialami oleh seseorang pesakit Covid-19 adalah berbeza antara satu sama lain kerana ia bergantung kepada keadaan kesihatan, persekitaran dan gaya hidup masing-masing (Universiti Utara Malaysia, 2020).

Berdasarkan laporan statistik yang dikeluarkan oleh WHO sehingga 31 Oktober 2020, sebanyak 45,475,639 kes positif dan 1,187,014 kes kematian disebabkan jangkitan Covid-19 telah dikesan melibatkan populasi di seluruh dunia dalam hanya tempoh 10 bulan penularannya (World Health Organization, 2020). Berikutan sifat penularan pandemik Covid-19 ini adalah secara global dan tahap kebolehjangkitan yang tinggi di antara satu individu kepada individu lain, maka ia menjadi suatu fenomena yang amat membimbangkan penduduk di seluruh dunia terutamanya melibatkan mereka yang tinggal atau berada dalam populasi dan kelompok masyarakat yang besar dan padat, termasuklah mereka yang sering bergerak dari suatu tempat ke tempat yang lain sehingga merentasi sempadan negara atas suatu tujuan tertentu Kementerian Kesihatan Malaysia, 2020). Apa yang lebih merisaukan ialah ancaman jangkitan virus ini yang tidak mengenal usia sasarannya, sehinggakan bayi seawal usia turut menjadi korban.

Dalam usaha untuk memerangi ancaman dan membendung penularan pandemik Covid-19 di negara ini, Kerajaan selaras dengan prosedur yang ditetapkan oleh WHO serta nasihat daripada KKM dan Majlis Keselamatan Negara (MKN) telah mengisytiharkan Perintah Kawalan Pergerakan (PKP) di bawah Akta Pencegahan dan Pengawalan Penyakit Berjangkit 1988 dan Akta Polis 1967 mulai 18 Mac 2020 bagi mengawal pergerakan rakyat di seluruh negara. Sehingga kini, Malaysia telah melaksanakan tujuh (7) fasa PKP di seluruh negara; iaitu empat (4) fasa PKP bagi tempoh 18 Mac hingga 31 Mac 2020 (PKP Fasa 1), 1 April hingga 14 April 2020 (PKP Fasa 2), 15 April hingga 28 April 2020 (PKP Fasa 3) dan 29 April hingga 12 Mei 2020 (PKP Fasa 4), satu (1) fasa Perintah Kawalan Pergerakan Bersyarat (PKPB - PKP Fasa 5) bagi tempoh 13 Mei hingga 9 Jun 2020 dan dua (2) fasa Perintah Kawalan Pergerakan Pemulihan (PKPP) bagi tempoh 10 Jun hingga 31 Ogos 2020 (PKP Fasa 6) dan yang sedang berlangsung ketika ini ialah PKP Fasa 7 mulai 1 September hingga 31 Disember 2020 (Majlis Keselamatan Negara, 2020 dan Wikipedia, 2020). Di antara tempoh pelaksanaan PKP Fasa 6 dan Fasa 7 tersebut telah berlaku gelombang ketiga pandemik Covid-19 di negara ini dan menyebabkan Kerajaan perlu mengeluarkan arahan pelaksanaan PKPB dan PKP Diperketatkan (PKPD) di beberapa buah negeri atau daerah atau kawasan setempat tertentu yang mencatatkan peningkatan kes positif Covid-19 yang tinggi. Persoalan sehingga bila pelaksanaan PKP ini akan berterusan dan bila ianya dapat ditamatkan adalah bergantung kepada usaha dan kerjasama daripada semua pihak untuk mematuhi segala saranan dan nasihat yang dikeluarkan oleh Kerajaan bagi memutuskan rantaian Covid-19 sepanjang tempoh PKP dilaksanakan.

Semasa pelaksanaan empat (4) fasa PKP yang pertama, Kerajaan telah menetapkan larangan menyeluruh terhadap pergerakan dan perhimpunan ramai di seluruh negara termasuk aktiviti keagamaan, sukan, sosial dan budaya. Semua perjalanan rakyat ke luar negara dan kemasukan semua pelancong dan pelawat asing ke dalam negara turut disekat bagi membendung penularan pandemik ini. Selain itu, semua institusi pendidikan rendah, menengah, pra-universiti, institusi pendidikan tinggi (IPT) dan institut latihan kemahiran sama ada awam ataupun swasta di seluruh negara juga diarahkan untuk ditutup. Kerajaan juga mengarahkan penutupan semua premis kerajaan dan swasta kecuali yang terlibat dengan perkhidmatan penting negara (essential services) sahaja (Majlis Keselamatan Negara, 2020 dan Jabatan Perdana Menteri, 2020a). Namun begitu, semasa fasa PKPB dan PKPP, Kerajaan telah memberi kelonggaran tertentu pada syarat-syarat PKP yang ditetapkan sebelum ini bagi membolehkan pembukaan semula sektor ekonomi secara terkawal bermula 13 Mei 2020 (Jabatan Perdana Menteri, 2020c) dan pembukaan semula sektor-sektor lain termasuk pendidikan secara berperingkat mulai 10 Jun 2020 dengan syarat mematuhi SOP yang ditetapkan sepenuhnya (Jabatan Perdana Menteri, 2020d).

Memandangkan sehingga kini, masih tiada lagi prosedur rawatan khusus atau ubat antivirus untuk mengubati jangkitan COVID-19 dan rawatan yang diberikan di hospital hanyalah untuk mengurangkan gejala yang dialami pesakit, maka KKM menyarankan agar rakyat untuk mengambil langkah kendiri dengan mendisiplinkan diri untuk terus kekal berada di rumah dan mengambil langkah-langkah pencegahan sebagai vaksin terbaik bagi mengelak jangkitan virus Covid-19 melalui 
Amalan 3W; iaitu kerap mencuci tangan dengan air dan sabun (Wash), sentiasa memakai pelitup muka di tempat awam (Wear) dan mematuhi amaran dari KKM (Warn) iaitu elakkan bersalaman/bersentuhan dengan orang lain, amalkan etika batuk dan bersin yang betul, dapatkan rawatan segera jika bergejala dan elakkan kunjung-mengunjungi serta melakukan aktiviti disinfeksi dan pembersihan kawasan yang kerap disentuh. Rakyat juga dinasihatkan agar sentiasa mengamalkan norma baharu dalam kehidupan seharian dengan melakukan penjarakan fizikal sekurang-kurangnya satu (1) meter pada setiap masa, elakkan tempat yang sesak, sempit dan tertutup dan bersembang dengan jarak yang dekat sebagai cara untuk membantu negara dalam memutuskan rantaian jangkitan Covid-19 (Kementerian Kesihatan Malaysia, 2020).

Sungguhpun terdapat pelbagai usaha yang sedang dilakukan dan langkah-langkah pencegahan yang telah ditentukan oleh Kerajaan, tetapi situasi penularan pandemik Covid-19 yang masih berlanjutan dan pelaksanaan PKP yang berterusan pastinya menimbulkan kesulitan dan kesukaran kepada rakyat untuk menjalani kehidupan seharian dengan selesa. Sebagai alternatifnya, mereka perlu menerapkan norma-norma baharu bagi kelangsungan hidup yang lebih sihat dan selamat. Namun demikian, sebagai rakyat yang prihatin perlulah melihat perkara ini dari perspektif yang lebih luas kerana bukan sahaja Malaysia malah seluruh dunia sangat terkesan dengan krisis pandemik Covid-19 ini kerana ia memberi impak yang lebih besar, mendalam dan berpanjangan terhadap pelbagai sektor penting negara seperti ekonomi, keselamatan, kesihatan, sosial dan sektor-sektor lain termasuklah sektor pendidikan.

\section{Isu dan Cabaran dalam Pelaksanaan Pendidikan Peringkat Rendah dan Menengah Semasa Penularan Pandemik Covid-19}

Kerajaan telah mengambil keputusan mengumumkan penutupan sepenuhnya institusi-institusi pendidikan di peringkat rendah dan menengah yang melibatkan semua sekolah kerajaan dan swasta serta lain-lain institusi pendidikan rendah dan menengah di seluruh negara bermula PKP Fasa 1 pada 18 Mac 2020 dan berterusan sehingga PKP Fasa 5 yang berakhir pada 9 Jun 2020. Arahan ini adalah suatu tindakan drastik yang perlu dilakukan oleh Kerajaan untuk membendung penularan pandemik Covid-19 di samping untuk menjaga keselamatan dan kesihatan murid-murid daripada terkena jangkitan Covid-19. Hal ini demikian kerana golongan kanak-kanak terutamanya yang berumur 12 tahun ke bawah adalah antara yang paling berisiko tinggi dan mudah dijangkiti virus Covid-19 (Kementerian Kesihatan Malaysia, 2020). Dalam pada itu, Perdana Menteri pada 10 April 2020 telah meminta KPM untuk melaksanakan inisiatif pembelajaran dari rumah atau home-based learning sepanjang tempoh PKP sehinggalah sekolah dibenarkan untuk dibuka semula (Jabatan Perdana Menteri, 2020b).

Dengan arahan penutupan sesi persekolahan tersebut, sudah tentu KPM berdepan dengan pelbagai isu dan cabaran dalam mencari pendekatan dan kaedah yang terbaik untuk memastikan proses pengajaran dan pembelajaran (PdP) dapat diteruskan sebagaimana saranan Perdana Menteri agar struktur PdP dari kaedah bersemuka di dalam bilik darjah kepada kaedah pembelajaran dari rumah semasa tempoh PKP. Keadaan ini sememangnya telah mengubah amalan pendidikan di negara ini dan pada awalnya pasti sukar untuk diadaptasi serta memberi kesan kepada semua pihak terutamanya tenaga pengajar dan murid-murid yang berada di rumah. Dalam keadaan pergerakan yang terbatas, guru-guru perlu membuat persediaan dan menyusun kaedah PdP yang bersesuaian, sementara murid-murid pula perlu bersedia menghadapi sesi pembelajaran secara dalam talian sepenuhnya termasuklah calon-calon murid yang bakal menduduki peperiksaan awam pada tahun 2020. Lain daripada itu, arahan pembukaan semula sekolah secara berperingkat selepas tempoh PKP Fasa 5 juga pastinya mengundang kebimbangan dalam kalangan ibu bapa tentang persediaan yang perlu dilakukan oleh anak-anak dalam mempersiapkan diri untuk kembali ke sekolah dengan mengaplikasikan norma baharu yang ditetapkan apabila berada di tempat awam. Begitu juga halnya kepada pihak pentadbir sekolah dan guru-guru perlu memainkan peranan masing-masing dalam mempersiapkan diri untuk memulakan takwim persekolahan yang telah dipinda dan menyediakan fasiliti yang mencukupi untuk memulakan sesi persekolahan mengikut SOP yang ditetapkan oleh KPM. 
DOI: https://doi.org/10.47405/mjssh.v6i9.1043

\section{Pendekatan Pengajaran dan Pembelajaran Dari Rumah}

Semasa pelaksanaan PKP di peringkat awal, kaedah PdP secara bersemuka telah diubah kepada kaedah PdP dari rumah sepenuhnya bagi mengawal pergerakan khususnya guru dan murid di samping untuk memastikan kesihatan dan keselamatan mereka daripada jangkitan Covid-19. Inisiatif yang dinaungi oleh KPM ini adalah untuk memastikan kelangsungan sesi PdP kepada murid-murid. Pelbagai pendekatan PdP secara dalam talian dan kaedah-kaedah yang bersesuaian telah dilaksanakan oleh pihak KPM, Jabatan Pendidikan Negeri, Jabatan Pendidikan Daerah, pentadbir sekolah dan guruguru seperti menggunakan aplikasi Google Classroom, CikgooTUBE, Quizizz, Wordwall, Kahoot, Youtube dan Zoom untuk menyampaikan maklumat pembelajaran kepada murid-murid yang berada di rumah. Sementara itu, bagi memudahkan komunikasi guru-guru dengan ibu bapa/penjaga dan muridmurid pula, aplikasi WhatsApp dan Telegram juga digunakan.

Bagi tujuan penyelarasan dan memastikan murid mendapat akses kepada PdP secara meluas, KPM telah bertindak proaktif dengan mengeluarkan Manual Pengajaran dan Pembelajaran di Rumah (PdPR) pada Oktober 2020 sebagai panduan kepada guru-guru untuk melaksanakan alternatif pembelajaran norma baharu melalui PdPR secara berstruktur dan terancang serta membolehkan murid-murid mengikuti PdPR secara optimum. PdPR ini boleh dilaksanakan secara dalam talian atau luar talian atau secara off-site di lokasi-lokasi seperti rumah atau pusat komuniti atau di mana-mana lokasi yang bersesuaian apabila murid-murid tidak dapat hadir ke sekolah dalam satu tempoh tertentu disebabkan oleh bencana atau wabak atau sebab-sebab lain dengan kelulusan pendaftar negeri. Bagi pelaksanaan PdPR secara dalam talian, capaian internet dan penggunaan peranti tertentu seperti komputer, komputer riba, tablet atau telefon pintar diperlukan bagi membolehkan pembelajaran secara real time dalam tempoh layar (screen time) dapat dilakukan. Pelantar pembelajaran yang boleh digunakan untuk PdPR secara dalam talian adalah seperti Digital Educational Learning Initiative Malaysia (DELIMa), Cikgootube, EduWebTV dan lain-lain aplikasi media sosial. Selain itu, aplikasi secara lintas langsung (live streaming) seperti Google Meet atau Microsoft Teams juga boleh digunakan dalam proses PdPR ini, selain atas kreativiti guru untuk menyediakan bahan pembelajaran interaktif yang lain seperti ePermainan (gamification), video, klip audio, eBuku, rakaman atau tugasan dalam talian. Namun begitu, terdapat kekangan dalam kaedah PdPR secara dalam talian ini kerana menurut WHO dan The American Academy of Pediatrics (AAP), terdapat tempoh layar atau masa penggunaan peranti maksimum yang perlu dipatuhi iaitu 1 hingga 2 jam bagi murid peringkat rendah, 2 hingga 3 jam bagi murid peringkat menengah rendah dan 3 hingga 4 jam bagi murid menengah atas (Kementerian Pendidikan Malaysia, 2020a).

Walaupun Manual PdPR telah dikeluarkan, namun keberkesanan pelaksanaan PdPR ini sangat menuntut usaha dan kerjasama padu daripada semua pihak berkepentingan seperti pentadbir sekolah, guru, ibu bapa/penjaga dan murid itu sendiri. Antara lain, peranan dan komitmen guru adalah yang terbesar dalam pelaksanaan PdPR ini kerana perlu menyusun semula Rancangan Pengajaran Tahunan (RPT) dan Rancangan Pengajaran Harian (RPH) supaya kandungan kurikulum dapat disampaikan dengan optimum, menentukan kaedah penyampaian yang fleksibel mengikut situasi semasa dengan mengambil kira sumber yang ada pada murid, menyediakan bahan pembelajaran yang mudah didapati, diakses dan boleh disesuaikan dengan kaedah PdPR yang digunakan, memastikan murid mendapat tugasan/latihan yang dirancang oleh guru, menggunakan kaedah pentaksiran yang bersesuaian untuk menentukan pencapaian murid dan merekod penglibatan murid dalam PdPR. Pentadbir sekolah pula perlu memastikan perancangan dan pengurusan PdPR dapat dilaksanakan dengan teliti, cekap dan berkesan bagi mengelakkan pertindanan masa antara mata pelajaran dan lambakan tugasan/latihan kepada murid. Sementera itu, ibu bapa atau penjaga juga perlu turut serta menjayakannya dengan membantu anak-anak di rumah bagi mendapatkan dan mengakses maklumat pembelajaran melalui kaedah PdPR mengikut sesi yang ditentukan oleh guru (Kementerian Pendidikan Malaysia, 2020a).

Selain itu, dengan mengambil kira pelaksanaan PdPR secara dalam talian ini masih baharu dalam sistem pendidikan di negara, pastinya terdapat banyak kekangan dalam pelaksanaannya serta keluhan yang didengari daripada guru, ibu bapa dan murid. Hal ini kerana tidak semua guru bersedia serta mempunyai pengetahuan dan kemahiran yang mencukupi dalam melaksanakan proses PdP secara dalam talian. Begitu juga kepada ibu bapa dan murid, tidak semua mempunyai peranti digital dan 
akses internet di rumah atau yang mencukupi bagi membolehkan proses pembelajaran secara dalam talian berlaku secara berterusan khususnya bagi murid-murid yang tinggal di kawasan pedalaman dan tidak berkemampuan. Permasalahan ini turut diakui oleh Menteri Kanan Pendidikan yang menyatakan bahawa terdapat kelemahan dalam pelaksanaan pembelajaran secara dalam talian kerana kaedah homebased learning adalah suatu perkara baharu dalam kalangan guru, murid dan ibu bapa. Selain itu, ramai murid yang tidak dapat mengikuti pembelajaran secara dalam talian kerana akses kepada teknologi komunikasi yang terhad. Ini menyebabkan keberkesanan PdP yang berasaskan home-based learning agak terhad jika dibandingkan dengan kaedah secara bersemuka. Menteri Kanan Pendidikan juga menyatakan kebimbangan mengenai situasi ini sekiranya berterusan akan mengakibatkan murid menghadapi kesukaran untuk mencapai tahap penguasaan minimum dalam setiap mata pelajaran yang diikuti. Seterusnya, ia akan memberi kesan kepada minat dan motivasi murid untuk terus mengikuti PdP (Kementerian Pendidikan Malaysia, 2020f). Di samping itu, isu dan cabaran dalam PdP secara dalam talian ini juga ditekan oleh Perdana Menteri Malaysia yang menyarankan agar KPM terus memperkasakan proses pendigitalan dengan menggunakan platform dalam talian atau pembelajaran maya demi masa depan pendidikan negara ini. Guru-guru juga diseru supaya mendalami kemahiran pengajaran secara dalam talian dan menjadikan home-based learning sebagai kebiasaan baharu dalam bidang perguruan (Kementerian Pendidikan Malaysia, 2020d).

Pada masa ini, terdapat banyak jurnal dan artikel yang ditulis berkaitan isu dan cabaran dalam pelaksanaan pendidikan semasa penularan pandemik Covid-19. Antaranya, menurut Nor Fauziana (2020), pelbagai aplikasi atau platform digital yang bersesuaian boleh digunakan seperti WhatsApp, Google Classroom, Zoom, Webex, YouTube dan sebagainya untuk meneruskan aktiviti PdP di rumah. Namun begitu, kaedah PdP secara atas talian ini menuntut komitmen dan kerjasama daripada semua pihak terutamanya dari segi pengetahuan dan kemahiran berkaitan teknologi maklumat, penyediaan peranti digital dan akses capaian internet yang berkualiti serta penyediaan kaedah penilaian yang bersesuaian bagi mengukur pencapaian pelajar khususnya murid-murid di peringkat rendah dan menengah. Bagi Wan (2020) pula, situasi Covid-19 telah menunjukkan jurang digital yang besar dalam kalangan murid di Malaysia. Pembelajaran secara dalam talian memerlukan murid untuk mempunyai akses kepada platform tertentu dan bimbingan daripada ibu bapa amat diperlukan. Prasyarat untuk belajar secara dalam talian pula memerlukan murid untuk mempunyai internet dan peranti digital. Berdasarkan kajian di kawasan bandar, didapati kanak-kanak perlu berkongsi peranti dan mereka tidak dapat mengakses sepenuhnya pelajaran dalam talian kerana capaian internet yang perlahan. Walau bagaimanapun, di kawasan pedalaman pula seperti perkampungan Orang Asli di Semenanjung, Sabah dan Sarawak, liputan internet adalah sangat terhad. Selain itu, ibu bapa juga perlu dididik untuk membolehkan mereka membimbing anak-anak. Kanak-kanak yang ibu bapanya kurang berpendidikan akan ketinggalan untuk belajar secara dalam talian. Krisis ini menunjukkan bahawa sistem pendidikan negara ini masih mempunyai kelemahan dari segi kesiapsiagaan digitalnya. Namun begitu, isu ini bukan sahaja berlaku di negara ini malah di kebanyakan negara di seluruh dunia yang berhadapan dengan perubahan dalam kaedah pendidikan dari bilik darjah ke dalam talian. Masih ramai guru tidak celik teknologi dan terpaksa menyesuaikan diri untuk melaksanakan pengajaran secara dalam talian.

Pandangan yang sama turut dilontarkan oleh Rahayu et al. (2020) yang menyatakan bahawa guru mestilah mempunyai tahap kesediaan dan kepekaan yang tinggi dalam menghadapi perubahan persekitaran yang sentiasa berubah-ubah, lebih-lebih lagi dalam mendepani cabaran dalam dunia pendidikan. Oleh itu, guru masa kini perlukan persediaan jitu yang menjangkaui batas sempadan pendidikan dan peradaban manusia selain perlu fleksibel terhadap keperluan semasa dan pada masa akan datang. Najib et al. (2020) pula menyatakan bahawa terdapat banyak kajian menunjukkan cabaran yang dihadapi melalui pembelajaran dalam talian di seluruh dunia. Antaranya ialah masalah kebergantungan kepada capaian internet apabila proses pembelajaran dilakukan serentak, kesukaran guru untuk mendapatkan bahan pengajaran dalam talian serta terdapat guru dan murid yang tidak mempunyai kemahiran digital yang sesuai untuk mengajar dan belajar dalam talian. Keadaan ini boleh menyebabkan proses pengajaran dan pembelajaran lebih menyukarkan.

Dalam pada itu, perubahan dalam cara menerima dan menyampaikan pendidikan semasa pandemik Covid-19 dilihat oleh Dhawan (2020) sebagai suatu langkah untuk menerapkan inovasi dan perubahan 
dalam kaedah pengajaran secara bersemuka. Walaupun guru sukar untuk menerima perubahan dalam kaedah pengajaran, namun dalam krisis ini tiada alternatif lain selain menyesuaikan diri dengan keadaan dinamik dan menerima perubahan tersebut. Keadaan ini juga akan memberi manfaat kepada sektor pendidikan dan boleh membawa kepada lebih banyak inovasi dalam sistem pendidikan. Walau bagaimanapun, masalah murid-murid yang tidak mempunyai akses kepada semua teknologi dalam talian perlulah diambil perhatian kerana ia akan menyebabkan berlakunya jurang digital sekali gus meluaskan jurang ketidaksamaan. Mohd Amirul (2020) pula memberikan pandangannya bahawa sekiranya pembelajaran secara elektronik (e-learning) melibatkan murid-murid luar bandar tidak dapat dilaksanakan sepenuhnya, ia membabitkan kadar relatif jurang digital atau digital divide iaitu mereka yang memiliki capaian maklumat dan yang tidak memiliki capaian maklumat disebabkan oleh perbezaan kadar kepantasan internet. Kefahaman bahawa e-learning di negara ini telah mencapai satu tahap yang membolehkan ia dilangsungkan tanpa sebarang masalah juga memerlukan audit yang menyeluruh. Ia bukan hanya berkisarkan aspek infrastruktur semata-mata tetapi juga melibatkan infostruktur, latar keupayaan ekonomi serta tahap kesediaan pihak-pihak yang terlibat dalam persekitaran e-learning itu sendiri.

Oleh yang demikian, dapat dilihat bahawa perubahan drastik dalam proses PdP di negara ini dari kaedah bersemuka di dalam bilik darjah kepada kaedah PdPR secara dalam talian masih berada di tahap penyesuaian oleh semua pihak. Namun begitu, segala inisiatif yang telah diambil sama ada oleh KPM, Jabatan Pendidikan Negeri, Jabatan Pendidikan Daerah, pentadbir sekolah, guru, ibu bapa/penjaga dan murid dalam memastikan kelangsungan proses PdPR ini perlulah diambil perhatian dan dihargai. Dalam masa yang sama, sebarang permasalahan yang timbul dalam pelaksanaan PdPR ini perlulah dibincangkan segera oleh pihak-pihak berkepentingan melalui platform yang bersesuaian agar kaedah dan penyelesaian terbaik dapat dicapai dalam memastikan proses PdP dapat diteruskan dan disalurkan kepada semua murid tanpa sebarang keciciran semasa PKP. Selain daripada isu perubahan dalam kaedah PdP serta kebimbangan dan kekangan yang dihadapi oleh ibu bapa/penjaga dan murid-murid dalam mendapatkan dan mengakses maklumat pembelajaran melalui kaedah PdPR secara dalam talian sepanjang tempoh PKP, pelaksanaan peperiksaan awam di peringkat rendah dan menengah rendah bagi tahun 2020 juga turut terjejas susulan daripada pengumuman KPM mengenai pembatalan Ujian Penilaian Sekolah Rendah (UPSR) dan Pentaksiran Tingkatan Tiga (PT3) bagi tahun 2020. Pembatalan UPSR dan PT3 ini tidak akan menjejaskan penilaian terhadap tahap penguasaan murid di peringkat rendah dan menengah rendah kerana penilaian boleh dilakukan dengan pelbagai kaedah lain. Namun begitu, memandangkan keputusan UPSR dan PT3 dijadikan sebagai satu daripada kriteria pemilihan murid untuk kemasukan ke sekolah-sekolah khusus seperti berasrama penuh (SBP), Sekolah Menengah Kebangsaan Agama (SMKA), Maktab Rendah Sains Mara (MRSM), Maktab Tentera Diraja (MTD) dan sekolah teknik, maka KPM akan memperkenalkan suatu kaedah baharu bagi tujuan pemilihan tersebut yang tidak hanya tertumpu kepada prestasi akademik sematamata (Kementerian Pendidikan Malaysia, 2020e).

Selain itu, KPM turut menjelaskan bahawa tiada peperiksaan ganti akan dikenakan kepada muridmurid yang perlu menduduki UPSR dan PT3 pada tahun ini (2020) dan penilaian terhadap penguasaan murid hanya akan dilakukan berdasarkan Pentaksiran Bilik Darjah (PBD) yang mana ia telah dilakukan oleh guru untuk satu tempoh yang panjang. KPM juga akan melaksanakan sebuah pentaksiran khas bagi murid-murid yang berhasrat untuk memasuki sekolah-sekolah khusus dan kaedah pentaksiran tersebut akan merangkumi keseluruhan potensi murid tanpa bergantung kepada pencapaian akademik semata-mata (Astro Awani, 2020).

\section{Pembatalan Peperiksaan Awam di Peringkat Rendah dan Menengah Rendah}

Walaupun KPM telah menetapkan tarikh untuk melaksanakan pentaksiran khas yang dipanggil Pentaksiran Kemasukan Sekolah Khusus (PKSK) bagi murid Tahun 6 dan murid Tingkatan 3 yang ingin memasuki sekolah khusus pada sesi persekolahan tahun 2021 mulai bulan Oktober, namun pelaksanaannya terpaksa ditangguhkan berikutan pelaksanaan PKPB di lima (5) buah negeri iaitu Sabah, Selangor, Wilayah Persekutuan Kuala Lumpur, Wilayah Persekutuan Putrajaya dan Wilayah Persekutuan Labuan akibat peningkatan kes jangkitan dalam gelombang ketiga Covid-19 di negeri- 
negeri tersebut. Kini, pelaksanaan PKPB berkenaan telah dilanjutkan selama empat (4) minggu lagi bermula 9 November 2020 hingga 6 Disember 2020 bagi lima (5) negeri tersebut termasuk negerinegeri lain di Semenanjung Malaysia kecuali negeri Kelantan, Pahang dan Perlis. Oleh itu, pada masa ini, KPM masih belum memaklumkan tarikh untuk melaksanakan PKSK tersebut kerana ia amat bergantung kepada situasi semasa pandemik Covid-19 dan hal ini tentunya turut menjejaskan tarikh kemasukan murid ke sekolah khusus yang dipilih pada sesi persekolahan tahun 2021 (Kementerian Pendidikan Malaysia, 2020e).

\section{Perubahan Tarikh Peperiksaan Awam di Peringkat Menengah Tinggi}

Meskipun Kerajaan telah bersetuju untuk membatalkan UPSR dan PT3 bagi sesi persekolahan tahun 2020, namun pelaksanaan peperiksaan awam tahun 2020 di peringkat menengah tinggi iaitu Sijil Pelajaran Malaysia (SPM), Sijil Vokasional Malaysia (SVM), Sijil Tinggi Persekolahan Malaysia (STPM) dan Sijil Tinggi Agama Malaysia (STAM) masih perlu diteruskan kerana penilaian murid di dalam peperiksaan tersebut adalah mustahak untuk menentukan pemilihan dan hala tuju pendidikan mereka ke peringkat pengajian tinggi. Dalam perkara ini, KPM pada peringkat awal telah mengumumkan penundaan tarikh peperiksaan SPM dan SVM kepada suku pertama tahun 2021. Sementara itu, untuk calon STPM pula, tarikh peperiksaan Semester 2 diubah kepada bulan Ogos 2020 manakala peperiksaan Semester 3 akan diadakan dalam suku pertama tahun 2021. Begitu juga dengan peperiksaan STAM akan diadakan dalam suku pertama tahun 2021. Selain itu, berikutan keputusan penundaan tarikh peperiksaan awam ini, ia turut memberi kesan kepada urusan kemasukan pelajar ke peringkat pengajian tinggi. Oleh itu, KPM dan Kementerian Pengajian Tinggi (KPT) telah bersetuju untuk menangguhkan tarikh kemasukan pelajar baharu ke institusi pengajian tinggi (IPT) bagi program asasi, matrikulasi dan peringkat diploma sehingga Julai atau Ogos 2021 manakala program ijazah sehingga September atau Oktober 2021 (Kementerian Pendidikan Malaysia, 2020e). Perancangan penundaan tarikh peperiksaan awam ini sekali lagi terjejas apabila negara ini berada dalam gelombang ketiga penularan Covid-19 yang mana telah menyebabkan pelaksanaan PKPB di beberapa buah negeri pada bulan Oktober 2020 dan seterusnya terpaksa dilanjutkan sehingga 6 Disember 2020 di seluruh negara kecuali di negeri Kelantan, Pahang, Perlis dan Sarawak. Mengambil kira situasi semasa Covid-19, KPM telah mengumumkan pemindaan tarikh peperiksaan SPM, SVM dan STAM iaitu bermula 22 Februari 2020, sementara STPM bermula 8 Mac 2021. Keputusan pemindaan tarikh peperiksaan awam tahun 2020 ini dibuat untuk memberi ruang kepada calon peperiksaan yang terkesan dengan penutupan sekolah untuk kembali semula ke sekolah pada awal tahun 2021 bagi membuat persediaan secukupnya sebelum menduduki peperiksaan tersebut (Kementerian Pendidikan Malaysia, 2020h).

\section{Pembukaan Semula Sesi Persekolahan Selepas PKP Fasa 5}

KPM pada 15 April 2020 telah memaklumkan bahawa pengumuman pembukaan semula sekolah akan dibuat sekurang-kurangnya dua (2) minggu awal sebelum sekolah dibuka. Keputusan pembukaan semula sekolah hanya akan dibuat apabila KPM berasa benar-benar yakin keadaan telah kembali pulih daripada ancaman pandemik Covid-19 setelah mendapat nasihat daripada pihak KKM. Keadaan ini perlu bagi mengelakkan kebimbangan yang timbul dalam kalangan ibu bapa/penjaga murid tentang persediaan yang perlu anak-anak mereka lakukan apabila kembali ke sekolah. Menurut KPM, semua aspek keselamatan, kebersihan dan pengawalan penularan jangkitan termasuklah amalan penjarakan fizikal akan diberi keutamaan bagi memastikan pengurusan sekolah dapat berjalan lancar dan sesi PdP dapat dilaksanakan dalam keadaan selamat (Kementerian Pendidikan Malaysia, 2020e).

Rentetan daripada pengumuman Kerajaan untuk membenarkan pembukaan semula sekolah semasa pelaksanaan PKPP (PKP Fasa 6) mulai 10 Jun 2020, KPM pada 10 Jun 2020 dan 1 Julai 2020 telah memaklumkan bahawa pembukaan semula sekolah akan dilaksanakan secara berperingkat berdasarkan saranan KKM dan MKN. Usaha ini didahului dengan kemasukan murid-murid kelas peperiksaan awam iaitu SPM, SVM, STPM dan STAM serta peperiksaan antarabangsa yang setara bermula pada 24 Jun 2020(Kementerian Pendidikan Malaysia, 2020f). Sementara bagi murid-murid bukan kelas 
peperiksaan awam pula, kemasukan semula ke sekolah bermula 15 Julai 2020 melibatkan murid Tingkatan 1 hingga Tingkatan 4, murid Kelas Peralihan dan murid Tahun 5 hingga Tahun 6, manakala murid Tahun 1 hingga Tahun 4 bermula pada 22 Julai 2020 (Kementerian Pendidikan Malaysia, 2020g).

Dalam menghadapi pembukaan semula sekolah ini, KPM menyeru agar semua ibu bapa/penjaga dapat memberi kerjasama dengan memastikan hanya anak-anak yang sihat sahaja dihantar ke sekolah, menasihati anak-anak agar sentiasa menjaga kebersihan dan memotivasikan anak-anak untuk terus belajar. Guru dan murid juga perlu mematuhi Garis Panduan Pengurusan Pembukaan Semula Sekolah yang telah dikeluarkan agar sesi pembelajaran dapat dilaksanakan dengan selamat. Sebagai norma baharu, suhu badan murid akan diperiksa terlebih dahulu apabila mereka memasuki pintu masuk sekolah, prosedur ini turut terpakai kepada guru, warga sekolah dan individu yang mempunyai urusan dengan pihak sekolah. Mereka yang mencatatkan suhu badan melebihi $37.5^{\circ} \mathrm{C}$ atau bergejala tidak akan dibenarkan masuk ke kawasan sekolah. Setelah itu, murid perlu mengikut laluan pergerakan terarah yang telah ditetapkan untuk menuju ke kelas masing-masing. Sepanjang berada di sekolah, murid perlu sentiasa menjaga kebersihan diri terutamanya amalan mencuci tangan dengan kerap. Selain itu, meja-meja di dalam kelas juga perlu disusun pada jarak sejauh satu (1) meter. Pergerakan murid-murid ketika waktu rehat turut disusun secara berperingkat bagi membolehkan murid beratur mengikut tanda penjarakan semasa membeli makanan dan minuman di kantin. Perkumpulan beramairamai do kantin tidak dibenarkan, justeru itu murid hanya dibenarkan makan di dalam kelas masingmasing dengan pengawasan guru. Bagi pelaksanaan aktiviti di luar bilik darjah seperti sukan dan kokurikulum secara bersemuka termasuk perhimpunan tidak dibenarkan sama sekali. Pendekatan ini turut melibatkan murid-murid yang menduduki asrama yang mana katil-katil dan meja di dewan makan disusun mengambil kira keperluan penjarakan fizikal (Kementerian Pendidikan Malaysia, 2020b dan Kementerian Pendidikan Malaysia, 2020c).

Namun begitu, bagi melaksanakan pembukaan semula sekolah secara sepenuhnya melibatkan kehadiran semua murid seperti keadaan biasa, ia telah menjadi suatu pertanyaan dan kebimbangan dalam kalangan ibu bapa/penjaga tentang bagaimana pengoperasian sekolah dapat dilaksanakan untuk menampung kehadiran murid yang ramai dengan mengambil kira keperluan penjarakan fizikal memandangkan ruang dan kapasiti sekolah yang berbeza-beza. Oleh yang demikian, KPM telah melaksanakan analisis dan mengenal pasti tiga (3) model pengoperasian pembukaan penuh sekolah sebagai panduan oleh pentadbir sekolah mengikut kesesuaian dan situasi sekolah masing-masing. Model yang diperkenalkan ialah Model Satu Sesi, Model Dua Sesi dan Model Penggiliran. Pelaksanaan Model Satu Sesi ialah untuk sekolah yang mempunyai bilik darjah atau ruang yang mencukupi bagi menempatkan semua murid dalam satu sesi setelah mengambil kira penjarakan fizikal. Model Dua Sesi pula ialah untuk sekolah sedia ada yang telah beroperasi secara dua sesi ataupun sekolah satu sesi yang perlu beroperasi secara dua sesi kerana tidak mempunyai ruang yang mencukupi bagi menempatkan semua murid dengan mengambil kira penjarakan fizikal. Sementara Model Penggiliran ialah untuk sekolah yang tidak mempunyai ruang yang mencukupi bagi menempatkan semua murid walaupun dengan melaksanakan model dua sesi. Dalam pelaksanaan Model Penggiliran di sekolah menengah, keutamaan perlu diberikan kepada murid Tingkatan 5 dan 6 supaya mereka dapat hadir ke sekolah setiap hari, manakala murid-murid lain perlu hadir secara bergilir-gilir mengikut kelas atau aliran tertentu yang ditetapkan oleh pihak pentadbir sekolah. Begitu juga pelaksanaannya di sekolah rendah, pihak pentadbir sekolah yang perlu menetapkan jadual penggiliran untuk kehadiran murid dari Tahun 1 hingga 6 mengikut kesesuaian kelas atau tahap. Berikutan tidak semua murid dapat hadir ke sekolah mengikut Model Penggiliran ini, maka KPM menetapkan agar kaedah pembelajaran murid dilaksanakan secara hibrid iaitu secara bersemuka apabila perlu hadir ke sekolah dan secara home-based learning apabila perlu berada di rumah (Kementerian Pendidikan Malaysia, 2020g).

Pada waktu yang sama, proses kemasukan semula murid sekolah berasrama juga diambil perhatian oleh KPM berikutan berlegar suara kebimbangan dalam kalangan ibu bapa yang menyuarakan bagaimana tahap keselamatan anak mereka apabila tinggal di asrama. Dalam mengatasi isu ini, KPM dengan kerjasama KKM telah meneliti langkah-langkah keselamatan yang perlu di asrama sekolah. Antara lain, pembukaan semula sekolah berasrama dilaksanakan mengikut kapasiti asrama sekolah 
masing-masing mengambil kira keperluan penjarakan fizikal yang ditetapkan. Asrama yang mempunyai kapasiti ruang yang terhad hanya dibenarkan untuk menempatkan sebahagian murid sahaja di asrama berikutan kekangan dalam penggunaan katil dua tingkat (double decker). Berdasarkan saranan KKM, hanya penggunaan katil bawah sahaja dibenarkan untuk peringkat awal kemasukan murid. Namun selepas tempoh 14 hari, kumpulan murid baharu oleh dibenarkan masuk ke asrama dengan menempatkan murid sedia ada di katil atas manakala murid baharu di katil bawah. Prosedur ini perlu diteruskan sehingga semua murid dapat tinggal di asrama (Kementerian Pendidikan Malaysia, 2020g).

\section{Pindaan Takwim Persekolahan Tahun 2020}

Berikutan ancaman pandemik Covid-19 adalah suatu situasi yang tidak pernah berlaku sebelum ini di negara ini, ia telah mendatangkan pelbagai isu dalam sektor pendidikan. Hal ini termasuklah dalam urusan pemindaan takwim persekolahan bagi tahun 2020 yang mana ia menjadi antara cabaran yang terbesar perlu dilakukan oleh KPM. Banyak perubahan perlu dilihat dan disesuaikan mengikut keadaan semasa dan juga mengambil kira kesannya di masa hadapan. Sebagai contoh perkara yang perlu diteliti oleh KPM adalah seperti penetapan semula tarikh peperiksaan awam khususnya SPM, SVM, STPM dan STAM tahun 2020. Perancangan yang rapi dalam menetapkan semula tarikh peperiksaan sangat perlu bagi membolehkan murid-murid mendapatkan masa yang cukup untuk membuat persediaan dari segi fizikal dan mental sebelum menghadapi peperiksaan kelak (Kementerian Pendidikan Malaysia, 2020g).

Walau bagaimanapun, pindaan takwim persekolahan perlu dilakukan sekali lagi di akhir-akhir sesi persekolahan tahun 2020 setelah Kerajaan pada 7 November 2020 mengumumkan pelaksanaan PKPB di seluruh negeri kecuali Kelantan, Pahang, Perlis dan Sarawak mulai 9 November 2020. Susulan daripada pengumuman tersebut, KPM memutuskan untuk menutup sesi persekolahan semua sekolah di bawah KPM bermula 9 November 2020 sehingga ke hari akhir persekolahan bagi tahun 2020 iaitu pada 17 Disember 2020 bagi negeri Kumpulan A dan 18 Disember 2020 bagi negeri Kumpulan B sebagai usaha untuk membantu Kerajaan memutuskan rantaian jangkitan pandemik Covid-19. Dengan keadaan sedemikian, sesi PdP akan terus dilaksanakan secara home-based learning mengikut kesesuaian guru dan murid dengan pengawasan oleh pentadbir sekolah masing-masing. Selain itu, ibu bapa/penjaga juga perlu mengambil anak-anak yang tinggal di asrama untuk pulang ke rumah masingmasing. Namun begitu, arahan pengambilan anak-anak di asrama ini tidaklah mendesak ibu bapa/penjaga untuk berbuat demikian dengan kadar segera, sebaliknya anak-anak boleh terus berada di asrama dengan pengawasan warden asrama sehinggalah mereka diambil oleh ibu bapa/penjaga (Kementerian Pendidikan Malaysia, 2020h).

Mengikut Takwim Penggal dan Cuti Persekolahan Tahun 2021 yang telah dirancang oleh KPM, sesi persekolahan bagi tahun 2021 akan dilaksanakan secara bersemuka bermula pada 20 Januari 2021 melibatkan semua murid sekolah rendah, murid Tingkatan 1, Tingkatan 4, Tingkatan 5 dan Tingkatan 6 serta semua murid Kolej Vokasional. Walau bagaimanapun, bagi murid Tingkatan 2 dan Tingkatan 3, sesi persekolahan tahun 2021 akan bermula pada tarikh yang sama tetapi kaedah PdP akan dilaksanakan secara home-based learning mengikut kesesuaian guru dan murid sehinggalah tarikh untuk mereka kembali ke sekolah untuk sesi pembelajaran secara bersemuka pada 8 Mac 2021. Keputusan ini perlu melibatkan murid-murid Tingkatan 2 dan Tingkatan 3 adalah untuk memberi ruang kepada calon-calon peperiksaan awam tahun 2020 iaitu SPM, SVM dan STAM untuk kembali ke sekolah bagi sesi pembelajaran secara bersemuka sebelum menduduki peperiksaan yang akan bermula pada 22 Februari 2021 bagi SPM dan SVM serta pada 8 Mac 2020 bagi STAM. Menurut KPM lagi, segala perancangan atau keputusan yang dibuat berkaitan sektor pendidikan ini telah diteliti dan diperhalusi sedalam-dalamnya kerana ianya melibatkan pelbagai pihak berkepentingan dengan jumlah yang besar iaitu merangkumi lebih 5 juta orang murid, lebih 500,000 orang guru, pensyarah dan warga KPM yang mana aspek keselamatan dan kesihatan semua pihak berkepentingan tersebut amat dititikberatkan (Kementerian Pendidikan Malaysia, 2020h). 


\section{Kesimpulan}

Sistem pendidikan dan pelaksanaan PdP di Malaysia pada hari ini telah melalui banyak perubahan drastik dan memberi kesan kepada pihak-pihak berkepentingan khususnya guru dan murid sejak mula arahan PKP diumumkan oleh Kerajaan sehingga kini. Proses PdP secara bersemuka yang diamalkan sebelum ini tidak dapat dilaksanakan apabila sekolah-sekolah perlu ditutup sepenuhnya, sebaliknya perlu diubah kepada kaedah home-based learning secara dalam talian atau kaedah-kaedah lain yang bersesuaian bagi memastikan kelangsungan proses PdP dan dalam masa yang sama tahap kemampuan murid juga perlu dilihat agar tidak berlaku keciciran dalam mengakses pelajaran sebagaimana hasrat Dasar Pendidikan Negara. Bagi membantu Kerajaan memerangi pandemik Covid-19 dan memastikan kesihatan dan keselamatan guru-guru dan murid-murid terus terpelihara, pelbagai isu dan cabaran yang timbul perlu dihadapi dan diatasi oleh KPM, antaranya melibatkan pembatalan peperiksaan UPSR dan PT3 serta pindaan tarikh peperiksaan awam peringkat menengah tinggi iaitu SPM, SVM, STPM dan STAM. Selain itu, KPM juga perlu mendepani isu-isu dan cabaran berkaitan pembukaan semula sekolah selepas tempoh PKP Fasa 5 dan pindaan terhadap takwim persekolahan tahun 2020. Semua perkara ini memerlukan penelitian dan perbincangan yang menyeluruh dengan pelbagai pihak agar segala keputusan dan pelaksanaan baharu yang dirancang dapat berjalan dengan lancar di samping impaknya terhadap sektor pendidikan pada masa hadapan dapat dikurangkan. Namun begitu, disebabkan PKPP masih terus dilaksanakan di seluruh negara dan negara juga masih berhadapan dengan kemelut gelombang ketiga Covid-19 melibatkan sebahagian besar negeri yang dilaksanakan PKPB berikutan peningkatan kes jangkitan Covid-19 yang tinggi pada masa ini, maka sebarang perubahan dan pindaan terhadap perancangan dan pendekatan-pendekatan yang sedang diambil oleh KPM berkaitan sektor pendidikan pada masa ini adalah dijangkakan. Dalam perkara ini, adalah penting bagi semua pihak untuk memberi kerjasama padu dan menyokong segala keputusan yang diumumkan agar ia tidak menjejaskan sektor pendidikan negara.

\section{Rujukan}

Dhawan, S. (2020). Online Learning: A Panacea in the Time of Covid-19 Crisis. Journal of Educational Technology Systems, 49(I) 5-22. doi:10.1177/0047239520934018. https://www.researchgate.net/publication/342344822

Jabatan Perdana Menteri (JPM). (2020a). Perutusan Khas YAB Perdana Menteri Mengenai COVID-19 - 16 Mac 2020. https://www.pmo.gov.my

Jabatan Perdana Menteri (JPM). (2020b). Perutusan Khas YAB Perdana Menteri - 10 April 2020. https://www.pmo.gov.my

Jabatan Perdana Menteri (JPM). (2020c). Perutusan Khas YAB Perdana Menteri - 23 April 2020. https://www.pmo.gov.my

Jabatan Perdana Menteri (JPM). (2020d). Perutusan Khas YAB Perdana Menteri Pelaksanaan Perintah Kawalan Pergerakan Pemulihan (PKPP) - 7 Jun 2020. https://www.pmo.gov.my

Kementerian Kesihatan Malaysia (KKM). (2020). Covid-19 Malaysia. https://covid-19.moh.gov.my

Kementerian Pendidikan Malaysia (KPM). (2013). Pelan Pembangunan Pendidikan Malaysia 20132025 (Pendidikan Prasekolah hingga Lepas Menengah). Putrajaya: KPM. https://www.moe.gov.my

Kementerian Pendidikan Malaysia (KPM). (2017). Dasar Pendidikan Kebangsaan (Edisi Keempat). Putrajaya: KPM. https://www.moe.gov.my

Kementerian Pendidikan Malaysia (KPM). (2020a). Manual Pengajaran dan Pembelajaran di Rumah. Putrajaya: KPM. https://www.moe.gov.my

Kementerian Pendidikan Malaysia (KPM). (2020b). Garis Panduan Pengurusan Pembukaan Semula Sekolah. Putrajaya: KPM. https://www.moe.gov.my

Kementerian Pendidikan Malaysia (KPM). (2020c). Garis Panduan Pengurusan dan Pengoperasian Sekolah Dalam Norma Baharu. Putrajaya: KPM. https://www.moe.gov.my

Kementerian Pendidikan Malaysia (KPM). (2020d). Teks Ucapan Perdana Menteri Malaysia: Hari Guru 2020. 16 Mei 2020. https://www.moe.gov.my

Kementerian Pendidikan Malaysia (KPM). (2020e). Teks Ucapan Sidang Media Menteri Kanan Pendidikan. 15 April 2020. https://www.moe.gov.my 
DOI: https://doi.org/10.47405/mjssh.v6i9.1043

Kementerian Pendidikan Malaysia (KPM). (2020f). Teks Ucapan Menteri Kanan Pendidikan: Pengumuman Tarikh Pembukaan Semula Sekolah. 10 Jun 2020. https://www.moe.gov.my

Kementerian Pendidikan Malaysia (KPM). (2020g). Teks Ucapan Menteri Kanan Pendidikan: Pembukaan Semula Sekolah Bagi Murid Bukan Kelas Peperiksaan Awam. 1 Julai 2020. https://www.moe.gov.my

Kementerian Pendidikan Malaysia (KPM). (2020h). Teks Ucapan Menteri Kanan Pendidikan: Pengoperasian Institusi Pendidikan di Bawah KPM Serta Peperiksaan Awam Tahun 2020. 8 November 2020. https://www.moe.gov.my

Majlis Keselamatan Negara (MKN). (2020). Covid-19. https://www.mkn.gov.my/web/ms/ covid-19/

Mohd Amirul Akbar. (2020). Covid-19: Nyahkan pendidikan lapuk berasaskan peperiksaan. Malaysia Kini: 19 April 2020. Capaian daripada: https://www.malaysiakini.com

Najib Yahaya Lawan, Ibrahim Isyaku Muhammad, Mudassir Lawal, Mubarak Ismail Shitu, Abhishek Kumar Verma, Mayadhar Barik. (2020). Online Education During Covid-19 Periods. A Text Book of The SARS-CoV-2: Guidelines and Protocol Development, First Edition: 2020, Chapter 9 147164. Mewar University: India. doi:10.1111/tct.13225. https://www.researchgate.net/publication/343540739_ONLINE_EDUCATION_DURING_COVI D-19 PERIODS

Nor Fauziana Mohd Salleh. (2020). Pandemik Coronavirus (Covid-19): Pembelajaran dan Pengajaran Secara Atas Talian Suatu Keperluan di Malaysia. Kolej Komuniti Bentong: Pahang.https://www.researchgate.net/publication/342886967_PANDEMIK_CORONAVIRUS_C OVID19 PEMBELAJARAN DAN PENGAJARAN SECARA ATAS TALIAN SUATU KE PERLUAN_DI_MALAYSIA.pdf

Rahayu Ahamad Bahtiar, Sham Ibrahim, Halijah Ariffin, Nor Hazimah Ismail \& Wan Mohd Khairul Wan Isa. (2020). Peranan dan Cabaran Pemimpin Pendidikan Dalam Memastikan Matlamat dan Agenda Pendidikan Dilestari Dalam Tempoh Perintah Kawalan Pergerakan (PKP) Covid-19. Institut Aminuddin Baki: Kementerian Pendidikan Malaysia. https://iab.moe.edu.my/bahanportal/pemberitahuan/2020/2.\% 20PERANAN\%20DAN\%20CABARAN\%20PEMIMPIN\%20PENDIDIKAN.pdf

Universiti Utara Malaysia (UUM). (2020). Covid-19 Pandemic: An Awareness Exhibition. https://library.uum.edu.my/covid-19-pandemic-an-awareness-exhibition

Wan, Ya Shin. (2020). Education during Covid-19. Brief Ideas No. 19. Institute for Democracy and Economic Affairs (IDEAS): Kuala Lumpur. https://www.researchgate.net/ publication/340860261 Education during COVID-19

Wikipedia. (2020). Perintah Kawalan Pergerakan Malaysia 2020. https://ms.wikipedia.org/wiki/Perintah_Kawalan_Pergerakan_Malaysia_2020

World Health Organization (WHO). (2020). Coronavirus disease (COVID-19) pandemic. https://www.who.int/emergencies/diseases/novel-coronavirus-2019\# 